\title{
Pengaruh uncaria gambir roxb terhadap ulkus gaster dan kadar malondialdehid hewan coba yang diinduksi etanol
}

\author{
Miftah Irramah, Julizar, Lili Irawati \\ Medical Physics Departement of Medical Faculty, University of Andalas \\ Korespondensi: Miftah Irrahmah, email: miftahirramah@rocketmail.com
}

\begin{abstract}
Abstrak
Ulkus peptikum dapat disebabkan berbagai faktor, seperti konsumsi alkohol yang berlebih. Alkohol menginduksi ulkus dengan membentuk radikal bebas yang merusak integritas mukosa sehingga terjadi ulkus. Di masyarakat, pengobatan secara tradisional adalah dengan mengonsumsi gambir. Tujuan: Untuk melihat pengaruh gambir terstandarisasi terhadap perbaikan ulkus dan malondialdehid pada tikus yang diinduksi etanol. Metode: Penelitian ini menggunakan 25 ekor tikus putih jantan galur Wistar. Hewan coba dibagi atas 5 kelompok masing-masing $\mathrm{K}(-), \mathrm{K}(+), \mathrm{P} 1, \mathrm{P} 2$ dan P3. Selanjutnya diperlakukan sebagai berikut: Selama 4 hari $\mathrm{K}(-)$ mendapat $1 \mathrm{ml}$ aqua dest, $\mathrm{K}(+)$, P1, P2 dan P3 mendapat 0,01 ml etanol 50\%/kg BB. Hari ke-5 sampai hari ke $18, \mathrm{~K}(+)$ diberi aqua dest $1 \mathrm{ml}, \mathrm{P} 1, \mathrm{P} 2$ dan P3 masing-masing mendapat $1 \mathrm{ml}$ larutan gambir 50, 100 dan $200 \mathrm{mg} / \mathrm{kg}$ BB per oral. Hari ke-19 hewan coba diambil darahnya melalui vena juguralis untuk penentuan kadar MDA. Selanjutnya hewan coba didekapitasi, diambil gasternya untuk menentukan perbaikan ulkus menggunakan kriteria Barthel-Manja yang telah dimodifikasi. Kadar MDA ditentukan dengan metode Placer. Hasil: Gambir terstandarisasi dapat memperbaiki ulkus gaster pada hewan coba. Terdapat perbedaan perbaikan ulkus pada pemberian gambir terstandarisasi dengan dosis yang berbeda. Dosis yang memberikan efek maksimum adalah $200 \mathrm{mg} / \mathrm{kg}$ BB. Pemberian gambir terstandarisasi juga dapat menurunkan kadar MDA serum akibat keberadaan radikal bebas ROS yang diinduksi etanol. Kesimpulan: Gambir terstandarisasi mempunyai peluang untuk menjadi obat biofarmaka yang potensial untuk ulkus peptikum. Untuk itu diperlukan penelitian lebih lanjut untuk uji efek dan keamanannya pada manusia. Kata kunci: Gambir terstandarisasi; Ulkus Gaster; MDA
\end{abstract}

\begin{abstract}
Gastric ulcers can be caused by many factors, such as excessive alcohol consumption. Alcohol to induce ulcers by forming a reactive oxygen species (ROS). ROS will damage the mucosa integrity resulting the ulcers. In society, traditionally, to treatment this problem is Gambir. Objective: To investigate the effect Gambir on gastric ulcers and malondialdehyde in rats Induced Ethanol. Method: this study used 25 male rats Wistar strain, divided into 5 groups each $K(-), K(+), P 1, P 2$ and $P 3$. For 4 days $K(-)$ received $1 \mathrm{ml}$ aqua dest, $K(+), P 1, P 2$ and $P 3$ received $0.01 \mathrm{ml}$ of $50 \%$ ethanol $/ \mathrm{kg}$. The 5 th to 18 th day, $K(-)$ and $K(+)$ were given $1 \mathrm{ml}$ aqua dest, $P 1, P 2$ and $P 3$ got each $1 \mathrm{ml}$ solution Gambir 50, 100 and $200 \mathrm{mg} / \mathrm{kg}$ orally. The 19th, animal blood drawn through a juguralis vein, after that were decapitated. Gaster was taken to determinations of ulcer repair use the modified Barthel-Manja criteria. MDA levels were determined by Placer method. Results: Gambier could improve gastric ulcers. There are differences in ulcer repair on providing different doses. Dose, which gives the maximum effect, is $200 \mathrm{mg} / \mathrm{kg}$. The administration of Gambir can also reduce levels of MDA. Conclusion: Gambir have the opportunity to be a potential biopharmaca for gastric ulcer. It required further studies to test the effects and safety in humans.
\end{abstract}

Keywords: standardized Gambir; Gastric ulcers; MDA 


\section{PENDAHULUAN}

Ulkus peptikum atau tukak lambung dan di masyarakat lebih dikenal dengan sebutan penyakit maag, memiliki prevalensi berkisar antara $11-14 \%$ pada pria dan 8$11 \%$ pada wanita. Prevalensi ulkus peptikum di Indonesia pada beberapa penelitian ditemukan antara 6-15\% terutama pada usia 20-50 tahun. Ulkus peptikum dapat dijumpai pada semua umur dengan usia puncak 50-60 tahun. ${ }^{1}$ Menurut data terakhir WHO yang dipublikasikan Mei 2014, kematian akibat penyakit ulkus peptikum di Indonesia mencapai 1.081 atau $0,08 \%$ dari total kematian. $^{2}$

Dua tipe ulkus peptikum yang sering didapatkan adalah ulkus gaster dan ulkus duodenal. Nama ini berdasarkan lokasi di mana ulkus ini ditemukan. Ulkus gaster ditemukan di perut, sedangkan ulkus duodenal mulai dari usus kecil yang juga disebut dengan duodenum. ${ }^{3}$

Ulkus peptikum terjadi karena terdapatnya ketidakseimbangan antara faktor defensif dan agresif yang mempertahankan integritas mukosa lambung. Faktor defensif antara lain adalah: sekresi mukosa lambung; bikarbonat, aliran darah ke membran mukosa; kapasitas regenerasi epitel dan elaborasi dari prostaglandin. Sedangkan faktor agresif antara lain: Keasaman lambung, enzim peptik (faktor internal), infeksi oleh Helicobacter pylori, konsumsi alkohol yang berlebihan, obatobat NSAID, merokok, refluks gastrikduodenal dan hiperasiditas lambung. Apabila terjadi peningkatan faktor agresif atau penurunan faktor defensif maka dapat terjadi kerusakan pada mukosa lambung. ${ }^{3}$

Pemberian atau konsumsi etanol yang berlebihan dapat merusak sawar mukosa lambung dengan cara meningkatkan produksi radikal bebas berupa Reactive Oxygen Species (ROS) sehingga menurunkan kemampuan antioksidan seluler dalam mempertahankan keseimbangan faktor defensif dan agresif sehingga kerusakan mukosa lambung tak dapat dihindari. ${ }^{4} \mathrm{Di}$ samping itu etanol cepat berpenetrasi ke dalam mukosa lambung sehingga mengakibatkan terjadinya difusi balik $\mathrm{HCl}^{5} \mathrm{Hal}$ ini akan memperparah dan mempercepat kerusakan mukosa lambung.

Reactive Oxygen Species (ROS) adalah molekul kecil yang mengandung elektron tak berpasangan dan merupakan salah satu radikal bebas alami yang terdapat dalam tubuh. Senyawa ini bersifat oksidator kuat dan sangat reaktif berikatan dengan molekul di sekitarnya sehingga dapat merusak molekul jaringan. ${ }^{6}$ Meningkatnya kadar ROS dalam tubuh berimplikasi pada berbagai macam penyakit degeneratif seperti hipertensi, aterosklerosis diabetes, ulkus peptikum, dan penyakit kronis lainnya. ${ }^{7}$

Kehadiran radikal bebas ROS yang berlebih berpotensi merusak membran sel melalui serangkaian reaksi yang cukup kompleks yang dikenal dengan peroksidasi lipid (Lipid Peroxidation). Akhir dari reaksi ini adalah terputusnya rantai asam lemak menjadi malondialdehyde (MDA), 9-hidroksi- 
nonenal, 4-hidroksi-2-nonenal (HNE), pentana $\left(\mathrm{C}_{5} \mathrm{H}_{12}\right)$ dan etana $\left(\mathrm{C}_{2} \mathrm{H}_{6}\right)$. Peningkatan ROS dapat dideteksi dengan mengukur produk-produk di atas. Di antara seluruh produk di atas MDA merupakan produk yang bersifat stabil dan bertahan lebih lama di dalam darah sehingga dapat dijadikan indikator untuk menilai obatobat (senyawa-senyawa) yang bersifat antioksidan. $^{8}$

Tanaman gambir (Uncaria gambir [Hunter] Roxb) merupakan salah satu komoditas ekspor hasil perkebunan rakyat yang bernilai ekonomi tinggi dan prospektif untuk diusahakan secara komersial mengingat kegunaannya yang beragam. Berbagai senyawa kimia yang terkandung dalam getah gambir adalah, katekin, asam catechu tannat, pyrocatechol, quersetin dan berbagai alkaloid seperti dihidro gambirtaninna, gambirdina, gambirtanina, gambirina, isogambirina, auroparina, oksogambirtanin. ${ }^{9}$ Getah gambir terutama mengandung senyawa katekin yang sangat dibutuhkan dalam industri-industri farmasi, kosmetik, batik, cat, dan lain-lain.

Gambir terstandarisasi (GT) adalah ekstrak daun gambir (Uncaria gambir [Hunter] Roxb) yang diproses dengan cara tertentu mengandung katekin tidak kurang dari $90 \%(10)$. Katekin adalah zat aktif yang paling banyak terdapat pada ekstrak gambir. Berbagai penelitian telah pula dilakukan untuk meneliti kualitas, kadar dan aktivitas katekin yang terdapat dalam gambir. ${ }^{11,12,13}$ Musdja ${ }^{14}$, telah meneliti efek anti jamur katekin dan gambir berserta mekanismenya dalam disertasinya di
Fakultas Kedokteran UI. Penelitian tentang katekin yang berasal dari ekstrak gambir terstandarisasi terhadap Ulkus dan mekanisme melalui penghambatan pembentukan radikal bebas ROS belum pernah dilaporkan. Penelitian ini bertujuan untuk mengetahui efek kuratif GT terhadap Ulkus gaster hewan coba yang diinduksi etanol melalui aktivitas antioksidannya.

\section{METODE}

Penelitian ini menggunakan desain eksperimental post only control group. Dilakukan di Laboratorium Farmakologi Fakultas Farmasi Universitas Andalas, Laboratorium Biokimia, Laboratorium Biomedik, dan Laboratorium Patalogy Anatomi Fakultas Kedokteran Universitas Andalas.

GT diperoleh dari laboratorium Kimia Bahan Alam Fakultas Farmasi Universitas Andalas yang telah dilakukan uji baku mengandung katekin tidak kurang dari 90\%. Untuk Induksi ulkus digunakan larutan alkohol 50\%. Bahan untuk pembuatan preparat histologik antara lain: $\mathrm{NaCl}$ fisiologis; formalin 10\%; larutan xylol, blok parafin dan larutan pewarna Hematoxylin-Eosin. Bahan untuk penetapan kadar MDA digunakan antara lain: Reagen TBA dan Larutan standar MDA. Bahan untuk penetapan MDA semuanya pro analisis yang tersedia di Laboratorium Biokimia Fakultas Kedokteran Unand.

Alat-alat yang digunakan pada penelitian ini antara lain: kandang hewan coba; 
handspray, timbangan digital; sonde; surgery set; spuit $10 \mathrm{ml}$; jarum suntik $23 \mathrm{G}$; mikrotom; rak perwarnaan; objekglas; coverglas; mikroskop digital yang tersambung ke komputer; mikrotube; mikropipet; waterbath; vortex; magnetic stirer dan spektrofotometer spekctronic 21D UV-Vis;

Subjek penelitian yaitu dua puluh lima tikus putih jantan (Rattus novergicus) yang berumur kurang lebih 150-200 gram yang berumur sekitar 2-3 bulan. Diperoleh dari Laboratorium Hewan Coba Fakultas Farmasi Universitas Andalas.

Hewan coba sebelum digunakan terlebih dulu diaklitimasi lebih kurang satu minggu, ditempatkan di kandang yang berukuran $40 \times 30 \times 20 \mathrm{~cm}$. Setiap kandang berisi 1 ekor hewan coba. Setelah proses aklitimasi, hewan coba dibagi secara acak menjadi 5 kelompok, setiap kelompok terdiri dari 5 ekor hewan coba. Hewan coba diberi makan dan minum ad libitum. Selanjutnya diperlakukan sebagai berikut:

Induksi Ulkus dengan etanol:

Induksi ulkus dengan etanol mengacu pada La Casa $^{15}$ dengan perlakuan sebagai berikut: Kelompok I diberi 0,1 ml aquadest/hari. Kelompok II, III, IV dan V diberi $0,1 \mathrm{ml}$ etanol $50 \%$ setiap hari selama 4 hari melalui jarum oral. Selanjut diperlakukan sebagai berikut:

Kelompok I dan II diberi $1 \mathrm{ml}$ aquadest setiap hari. Kelompok III: diberi $1 \mathrm{ml}$ larutan GT dosis $50 \mathrm{mg} / \mathrm{kg}$ BB, Kelompok IV: diberi $1 \mathrm{ml}$ larutan GT dosis $100 \mathrm{mg} / \mathrm{kg}$ BB dan Kelompok V: diberi $1 \mathrm{ml}$ larutan GT dosis $200 \mathrm{mg} / \mathrm{kg}$ BB setiap hari melalui jarum oral selama 2 minggu.

\subsection{Pengambilan darah dan gaster.}

Setelah 14 hari perlakuan pemberian GT, semua hewan coba dipuasakan selama kurang lebih 8 jam. Ambil darah hewan coba melalui vena juguralis untuk penentuan kadar MDA. Selanjutnya hewan coba didekapitasi, diambil gasternya untuk dibuatkan preparat histologiknya. Penetapan perbaikan ulkus menggunakan kriteria Barthel-Manja yang telah dimodifikasi.

2. Pembuatan preparat Histologik gaster.

Gaster yang telah dipisahkan dari hewan coba dibersihkan dengan $\mathrm{NaCl}$ fisiologis, dan direndam dengan formalin $10 \%$ selama 1 hari. Selanjutnya dibawa ke laboratorium Patologi Anatomi untuk dibuatkan preparat histologinya dengan pewarnaan hematosiklin eosin (HE). Preparat yang sudah jadi diamati di bawah mikroskop elektronik dengan pembesaran 100X untuk dianalisis. Pembuatan gambar histologik dilakukan di Lab. Biomedik FK Unand.

\section{Penetapan MDA Serum Hewan coba}

Darah yang diperoleh disentrifus untuk dipisahkan serumnya. Selanjutnya tentukan kadar MDA setiap hewan coba dengan metode Placer ${ }^{16}$.

Pipet 0,1 mL serum, tambahkan 0,9 mL aquadest dan $0,5 \mathrm{~mL}$ reagen TBA. Homogenkan dengan menggunakan vortex. Selanjutnya inkubasi dalam waterbath selama 60 menit pada suhu 
$95^{\circ} \mathrm{C}$. Angkat dan dinginkan pada suhu kamar, kemudian disentrifus selama 10 menit dengan kecepatan $7000 \mathrm{rpm}$. Pisahkan filtrat. Selanjutnya supernatan diukur absorbannya dengan spektrofotometer pada panjang gelombang $532 \mathrm{~nm}$. Cara yang sama dilakukan terlebih dulu untuk 0,1 ml larutan standar MDA. Kadar MDA sampel dihitung dengan menggunakan persamaan berikut:

$$
\begin{gathered}
n=\frac{\text { absorban sampel }}{\text { absorban standar }} \times c . \text { standar } \\
\mathrm{n}=\text { Kadar MDA sampel }(\mathrm{nmol} / \mathrm{ml})
\end{gathered}
$$

\section{HASIL DAN PEMBAHASAN}

\section{Pemeriksaan Ulkus Gaster}

Efek kuratif gambir terhadap perbaikan ulkus peptik yang diinduksi etanol menggunakan indikator kerusakan integritas mukosa dengan kriteria BarthelManja. $^{3}$

Tabel 1. Indikator kerusakan integritas mukosa.

\begin{tabular}{ccl}
\hline No. & Skor & \multicolumn{1}{c}{ Integritas Mukosa } \\
\hline 1 & 0 & $\begin{array}{l}\text { Tidak ada perubahan } \\
\text { patologik }\end{array}$ \\
2 & 1 & $\begin{array}{l}\text { Deskuamasi epitel } \\
\text { Erosi permukaan epitel }\end{array}$ \\
4 & 2 & \begin{tabular}{l} 
Ulserasi epitel \\
\hline
\end{tabular} \\
\hline
\end{tabular}

Pada deskuamasi epitel terjadi kerusakan epitel, terdapat celah sampai sepertiga epitel mukosa. Erosi epitel terdapat kerusakan sebagian/separuh dari mukosa. Ulserasi epitel terjadi kerusakan hampir atau mencapai seluruh tebal mukosa.
Pada penelitian ini pemeriksaan integritas mukosa gaster untuk setiap organ hewan coba diperiksa pada lima lapangan pandang. Gambar 1 adalah contoh kerusakan integritas masing-masing kelompok perlakuan dengan skor kerusakan integritas mukosanya.
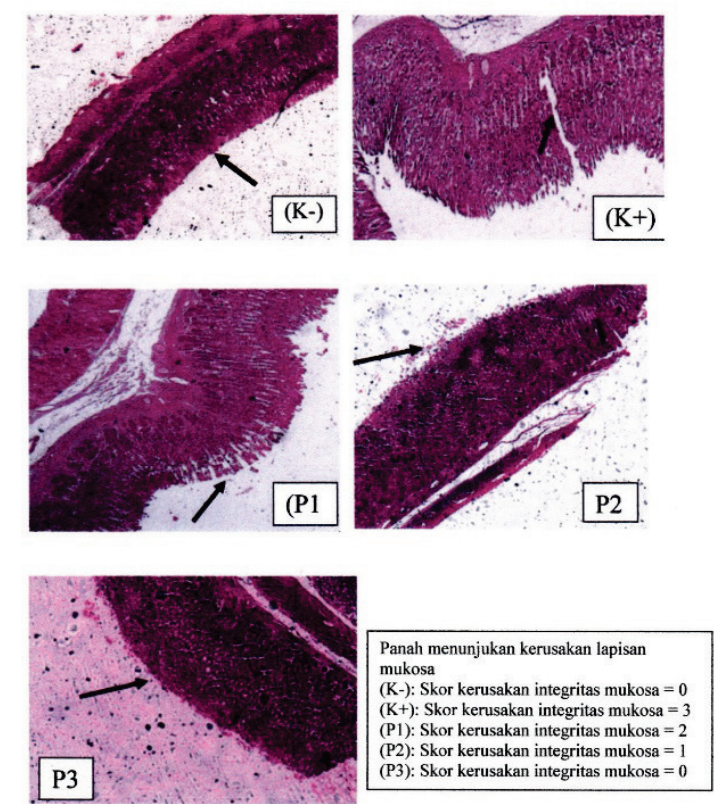

Gambar 1. Gambaran histologik gaster.

Data kerusakan mukosa gaster untuk masing-masing kelompok perlakuan diringkas pada tabel 2 .

Uji normalitas data kerusakan integritas mukosa per kelompok dengan ShapiroWilk Test didapat $p>0,05$, berarti data terdistribusi normal. Uji homogenitas juga didapatkan data yang homogen dengan $p>0,05$. Untuk melihat perbedaan perlakuan data dianalisis dengan menggunakan One Way Anova $(p<0,05)$ dan dilanjutkan dengan uji Post-Hoc LSD. 
Tabel 2. Skor kerusakan integritas mukosa gaster.

\begin{tabular}{|c|c|c|c|c|c|c|c|}
\hline \multirow{2}{*}{ Kelompok } & \multirow{2}{*}{$\begin{array}{c}\text { No. } \\
\text { sampel }\end{array}$} & \multicolumn{5}{|c|}{ skor desintegritas mukosa gaster } & \multirow{2}{*}{ Rerata/hewan } \\
\hline & & LP 1 & LP 2 & LP 3 & LP 4 & LP 5 & \\
\hline \multirow{5}{*}{ Kontrol - } & 1 & 0 & 0 & 0 & 0 & 0 & 0 \\
\hline & 2 & 0 & 0 & 0 & 0 & 0 & 0 \\
\hline & 3 & 0 & 0 & 0 & 0 & 0 & 0 \\
\hline & 4 & 0 & 0 & 0 & 0 & 1 & 0.2 \\
\hline & 5 & 0 & 0 & 1 & 1 & 0 & 0.4 \\
\hline \multirow{5}{*}{ Kontrol + } & 1 & 2 & 1 & 2 & 1 & 1 & 1.4 \\
\hline & 2 & 1 & 1 & 1 & 1 & 0 & 0.8 \\
\hline & 3 & 3 & 2 & 2 & 2 & 1 & 2 \\
\hline & 4 & 3 & 1 & 1 & 2 & 1 & 1.6 \\
\hline & 5 & 3 & 2 & 2 & 2 & 3 & 2.4 \\
\hline \multirow{5}{*}{ Perlakuan 1} & 1 & 1 & 2 & 1 & 1 & 3 & 1.6 \\
\hline & 2 & 0 & 1 & 2 & 1 & 1 & 1 \\
\hline & 3 & 1 & 2 & 1 & 1 & 1 & 1.2 \\
\hline & 4 & 2 & 3 & 1 & 1 & 1 & 1.6 \\
\hline & 5 & 0 & 0 & 2 & 2 & 2 & 1.2 \\
\hline \multirow{5}{*}{ Perlakuan 2} & 1 & 0 & 0 & 1 & 2 & 1 & 0.8 \\
\hline & 2 & 2 & 2 & 0 & 0 & 0 & 0.8 \\
\hline & 3 & 2 & 1 & 1 & 1 & 1 & 1.2 \\
\hline & 4 & 1 & 1 & 1 & 0 & 1 & 0.8 \\
\hline & 5 & 0 & 1 & 1 & 1 & 1 & 0.8 \\
\hline \multirow{5}{*}{ Perlakuan 3} & 1 & 0 & 0 & 0 & 0 & 0 & 0 \\
\hline & 2 & 0 & 0 & 0 & 0 & 0 & 0 \\
\hline & 3 & 0 & 0 & 0 & 1 & 1 & 0.4 \\
\hline & 4 & 1 & 1 & 1 & 1 & 0 & 0.8 \\
\hline & 5 & 0 & 1 & 0 & 0 & 0 & 0.2 \\
\hline
\end{tabular}

Hasil uji Post-Hoc LSD didapatkan perbedaan yang bermakna $(p<0,05)$ antara kelompok K(-) yang hanya mendapatkan aquadest selama perlakuan dengan kelompok $\mathrm{K}(+)$ yang mendapatkan etanol $1 \mathrm{ml}$ etanol $50 \%$ selama 4 hari dan selanjutnya mendapat $1 \mathrm{~mL}$ aquadest selama 14 hari berikutnya. Hal ini membuktikan bahwa pemberian $1 \mathrm{ml}$ etanol 50 selama 4 hari dapat menimbulkan kerusakan integritas mukosa gaster. Hasil penelitian sesuai dengan yang dilakukan oleh Khazaei dan Hussein ${ }^{17}$ dan yang dikemukakan oleh Amandeep ${ }^{18}$ bahwa etanol adalah salah satu penyebab terjadinya ulkus peptik. Hal yang sama juga dilaporkan oleh Fernandes-Checa dan Kaplowitz, bahwa etanol adalah salah satu senyawa yang dapat menyebabkan pembentukan ROS yang merusak mukosa saluran cerna. ${ }^{4}$ 
Bervariasinya skor kerusakan integritas mukosa pada $\mathrm{K}(+)$ mulai dari 0 sampai 3 , boleh jadi disebabkan respons individual yang bervariasi dalam mengatasi ulkus yang diinduksi. Skor 0 pada kelompok yang mendapat etanol ini boleh jadi disebabkan tidak semua luas permukaan mukosa yang terekspose. Banyaknya Skor 1 pada kelompok ini, hal ini dapat disebabkan individu lebih tahan terhadap ulkus dan proses regenerasi mukosa berjalan baik, sedangkan pada hewan coba yang skor kerusakan integritasnya 3 terjadi hal yang sebaliknya.

Tidak terdapat perbedaan yang bermakna antara kelompok $\mathrm{K}(+)$ dengan $\mathrm{P} 1$ yang mendapat gambir $50 \mathrm{mg} / \mathrm{kg}$ BB selama 14 hari. Hal ini menunjukkan bahwa pemberian gambir dengan dosis $50 \mathrm{mg} / \mathrm{kg}$ BB tidak bermakna memperbaiki ulkus. Terdapat perbedaan yang bermakna antara $\mathrm{K}(+)$ dengan $\mathrm{P} 2$ dan $\mathrm{P} 3$ yang samasama terinduksi ulkus. $\mathrm{Hal}$ ini membuktikan bahwa pemberian gambir dengan dosis 100 dan 200 mg/kg BB dapat memperbaiki ulkus yang diinduksi etanol. Tidak terdapat perbedaan yang bermakna antara Kelompok P3 dengan kontrol negatif. Hal ini menunjukkan bahwa pemberian gambir dengan dosis $200 \mathrm{mg} / \mathrm{kg}$ BB $(p>0,05)$ memberikan efek paling tinggi untuk perbaikan ulkus.

Adanya perbaikan ulkus pada kelompok yang mendapat gambir terutama pada kelompok yang mendapatkan dosis 200 $\mathrm{mg}$, boleh jadi disebabkan karena gambir mengandung antioksidan katekin yang menghambat proses pembentukan ROS oleh etanol. Analog dengan penelitian ini, Hamaishi ${ }^{19}$, telah membuktikan pemberian katekin yang berasal dari teh dapat memperbaiki kerusakan mukosa gaster. Hasil penelitian ini mirip juga dengan yang dilakukan oleh Sannomiya ${ }^{20}$, yang melaporkan flavonoid yang terdapat pada daun Byrsonima crassa bersifat antiulcerogenic. Sebagai mana diketahui katekin adalah salah satu dari sekian banyak jenis flavonoid. ${ }^{21}$

\section{Penetapan Kadar MDA}

Hasil penetapan kadar MDA dengan metode Placer didapatkan hasil seperti yang terlihat pada tabel 3.

Uji normalitas data MDA dengan ShapiroWilk Test didapat $p<0,05$, berarti data tidak terdistribusi normal. Untuk melihat perbedaan perlakuan data dianalisis dengan menggunakan Kruskal-Wallis $(p<0,05)$ dan dilanjutkan dengan uji MannWhitney.

Hasil uji Mann-Whitney didapatkan perbedaan yang bermakna $(p<0,05)$ antara kelompok $\mathrm{K}(-)$ yang hanya mendapat akuades dengan $\mathrm{K}(+)$ yang mendapat etanol dan kelompok P1 dan P2 yang juga mendapat etanol dan larutan GT dimana pada ke tiga kelompok yang mendapat etanol ini kadar MDA-nya lebih tinggi. Hal ini disebabkan karena etanol berpenetrasi cepat ke dalam mukosa lambung dengan cara memproduksi radikal bebas ROS. 5,15 Kehadiran radikal bebas ROS yang berlebih berpotensi merusak membran sel melalui serangkaian reaksi yang cukup kompleks yang dikenal dengan peroksidasi lipid (Lipid 
Peroxidation). Akhir dari reaksi ini adalah terputusnya rantai asam lemak menjadi malondialdehyde (MDA), 9-hidroksinonenol, 4-hidroksi-2-nonenol (HNE), pentana $\left(\mathrm{C}_{5} \mathrm{H}_{12}\right)$ dan etana $\left(\mathrm{C}_{2} \mathrm{H}_{6}\right) .{ }^{8}$ Peningkatan ROS dapat dideteksi dengan mengukur kadar MDA yang bersifat stabil dan bertahan lebih lama di dalam darah.

Tabel 3. Kadar MDA hewan coba

\begin{tabular}{cccc}
\hline Kelompok & Kode sampel & MDA $(\mu \mathrm{mol})$ & Rata-rata \pm SD $(\mu \mathrm{mol})$ \\
\hline \multirow{5}{*}{ Kontrol - } & $\mathrm{K}-1$ & 1,82 & \\
& $\mathrm{~K}-2$ & 2,74 & \\
& $\mathrm{~K}-3$ & 2,96 & \\
& $\mathrm{~K}-4$ & 2,79 & \\
& $\mathrm{~K}-5$ & 5,64 & \\
& $\mathrm{~K}+1$ & 4,12 & \\
Kontrol + & $\mathrm{K}+2$ & 3,08 \\
& $\mathrm{~K}+3$ & 5,44 \\
& $\mathrm{~K}+4$ & 9,24 \\
& $\mathrm{~K}+5$ & 4,27 \\
& P1-1 & 3,49 \\
& P1-2 & 3,81 \\
& P1-3 & 5,16 \\
& P1-4 & 3,85 \\
& P1-5 & 4,58 \\
& P2-1 & 3,66 \\
& P2-2 & 2,74 \\
& P2-3 & 3,61 \\
& P2-4 & 2,98 \\
& P2-5 & 3,73 \\
& P3-1 & 3,27 \\
& P3-2 & 3,71 \\
& P3-3 & 2,5 \\
& P3-4 & 2,72 \\
\hline
\end{tabular}

Terdapat perbedaan yang bermakna antara $\mathrm{K}(+)$ dengan $\mathrm{P} 3$ yang mendapat gambir 200 $\mathrm{mg} / \mathrm{kg}$ BB. Kadar MDA P3 tidak berbeda bermakna dengan $\mathrm{K}(-)$. Hal ini menunjukkan efek penurunan MDA sebagai indikator kerja antioksidan gambir bermakna pada dosis $200 \mathrm{mg} / \mathrm{kg}$ BB.

Rendahnya kadar MDA pada P3 disebabkan terdapatnya katekin pada larutan gambir yang bersifat anti oksidan. Salah satu cara kerja antioksidan adalah menghambat pembentukan ROS dengan cara menyumbangkan elektronnya sehingga produk MDA-nya juga berkurang. ${ }^{8}$

Tidak terdapat perbedaan kadar MDA yang bermakna antara kelompok $\mathrm{K}(+)$ yang mendapat $1 \mathrm{ml}$ akuades dengan $\mathrm{P} 1$ dan $\mathrm{P} 2$ yang mendapat $1 \mathrm{ml}$ larutan gambir masingmasing dengan dosis 50 dan $100 \mathrm{mg} / \mathrm{kg} \mathrm{BB}$ setelah pemberian etanol dihentikan. Hal ini menunjukkan bahwa dosis 50 dan 100 $\mathrm{mg} / \mathrm{kg}$ BB belum memberikan efek sebagai anti ulserasi pada hewan coba. Tidak terdapat perbedaan efek penurunan MDA antara P1 dengan P2 dan P2 dengan P3. 
Terdapat perbedaan penurunan MDA yang bermakna antara P1 yang mendapat gambir $50 \mathrm{mg}$ dengan $\mathrm{P} 3$ yang mendapat gambir $200 \mathrm{mg} / \mathrm{kg} \mathrm{BB}$. Hal ini memperkuat bahwa dosis $200 \mathrm{mg} / \mathrm{kg}$ BB merupakan dosis yang memberikan efek yang maksimal.

\section{KESIMPULAN}

Gambir terstandarisasi dapat memperbaiki ulkus gaster dan menurunkan kadar MDA serum akibat keberadaan radikal bebas ROS yang diinduksi etanol pada hewan coba. Terdapat perbedaan efek pada dosis yang berbeda dengan efek maksimum pada dosis $200 \mathrm{mg} / \mathrm{kg}$ BB. Disarankan untuk penelitian selanjutnya untuk meneliti mekanisme penurunan kadar
MDA oleh Gambir.

\section{DUKUNGAN FINANSIAL}

Penelitian ini didanai oleh Kementerian Riset dan Teknologi melalui dana PNPB 2016 Nomor 71/BBPT/PNP-FK-UNAND2016.

\section{UCAPAN TERIMA KASIH}

Atas selesainya penelitian ini, Penulis mengucapkan terima kasih kepada saudari Bella Yollanda sebagai pembantu peneliti utama; saudara Syafriaman, laboran hewan coba Fakultas Farmasi, dan para laboran/teknisi pada laboratorium Patologi Anatomi, Biokimia, dan Biomedik Fakultas Kedokteran Unand.

\section{DAFTAR PUSTAKA}

1. Tarigan P, Akil HAM. Tukak Gaster dan Tukak Duodenum. Dalam: Buku Ajar Ilmu Penyakit Dalam Edisi Keempat - Jilid I. Jakarta: Pusat Penerbitan Departemen IImu Penyakit Dalam Fakultas Kedokteran Universitas Indonesia. 2006. p.338

2. WHO. WORLD HEALTH RANKINGS Indonesia peptic ulcer disease http://www.worldlifeexpectancy.com/indonesia-peptic-ulcer-disease. 2014. Dikutip tanggal 11 Juni 2016

3. Robins KV dan Cotran RS. Buku Ajar Patologi Robbins, Edisi 7, Jakarta: EGC. 2012.

4. Fernandes-Checa JC, Kaplowits N. 2005. Hepatic mitochondrial glutathione: transport and role in disease and toxicity. Toxicol. Applied Pharm 2005; 204: 263-73.

5. Suleyman H, Mehmet EB, Koruk M. The Effects of Hippophae rhamnoides L. extract on etanol induced gastric lesion andgastric tissue glutathione level in rat: A comparative study with melatonin and omeprazol. Indian Journal of Pharmacoly. 2001;33: 77-81.

6. Valko M1, Leibfritz D, Moncol J, Cronin MT, Mazur M, Telser J. Free radicals and antioxidants in normal physiological functions and human disease. Int J Biochem Cell Biol; 2007. 39(1):44-84.

7. Paravicini TM, Touyz RM. NADPH oxidases, reactive oxygen species and hypertension. Diabetes Care. 2008; 31 (2): S170-180.

8. Ayala A, Muñoz MF, Argüelles S. Lipid Peroxidation: Production, Metabolism, and Signaling Mechanisms of Malondialdehyde and 4-Hydroxy-2-Nonenal. Oxidative Medicine and Cellular 
Longevity. Volume 2014 (2014), Article ID 360438, 31 pages

http://dx.doi.org/10.1155/2014/360438

9. Amir M, Mujeeb M, Khan A, Ashraf K, Sharma D, Aqil M. Phytochemical analysis and in vitro antioxidant activity of Uncaria gambir. Int J Green Pharm 2012;6:67-72.

10. BPOM Acuan Sediaan Herbal. Volume 5 edisi pertama. Badan Pemeriksaan Obat dan Makanan. RI. Jakarta. 2010.

11. Jain KM, Hussin MH, Achmad A, Dahon NH, Suan TK, Hamdan HS. Penentuan kandungan fenol total, tanin terkondensasi dan flavonoid dan aktivitas antioksidan ekstrak Uncaria gambir. Majalah Farmasi Indonesia, 2011;22(1):50-59.

12. Anggraini T, Tai A, Yoshino T, Itani T. Antioxidative activity and catechin content of four kinds of Uncaria gambir extracts from West Sumatra, Indonesia. African Journal of Biochemistry Research 2011;5(1):33-38.

13. Rahmawati N, Bachtiar A, Putra DP. Isolasi Katekin dari gambir (Uncaria gambir (Huntr (Roxb) untuk sediaan farmasi dan kosmetik. Jurnal Penelitian Farmasi Indonesia 2012;1(1):6-10.

14. Musdja, M Yanis. Uji aktivitas anti jamur katekin dan gambir (Uncaria gambir, roxb) terhadap beberapa jenis jamur dan mekanismenya. Disertasi pasca sarjana Fakultas Kedokteran UI. 2012.

15. La Casa C, Villegas I, Alarcón De La Lastra C, Motilva V, Martín Calero MJ. Evidence for protective and antioxidant properties of rutin, a natural flavone, against ethanol induced gastric lesions. J Ethnopharmacol. 2000;71(1-2):45-53.

16. Placer ZA, Cushman LL, Johnson BC. Estimation of product of lipid peroxidation (malonyl dialdehyde) in biochemical systems. Anal Biochem [Internet]. 1966;16(2):359-64. Available from: http://www.sciencedirect.com/science/article/pii/0003269766901679

17. Khazaei M, Hussein S. Protective Effect of Falacaria vulgaris Extract on ethanol Induced Gastric Ulcer in Rat. Iranian Jurnal of Pharmacology and Therapeutics. 2006;5:43-46.

18. Amandeep K, Robin S, Ramica S and Sunil K. A Review Etiology and Pathogenesis, International Research Journal of Pharmacy. 2012;3(6):34-38.

19. Hamaishi K, Kojima R, ito M. Antiulcer effect of tea catechin in rat. Pharmacetical society of Japan. 2006;29(11): 2206-13.

20. Sannomiya M. Flavonoids and antiulcerogenic activity from Brysonyma crassa leaves extracts. Journal of Ethnopharamcology. 2005;93:525-32.

21. Winarsi H. Antioksidan Alami dan radikal bebas: Potensi dan Aplikasinya dalam Kesehatan. Penerbit Kanisius, Yogyakarta. 2007. 